\title{
FEMALE STUDENT ACHIEVEMENT USING EDMODO IN THE ELEVENTH-GRADE ECONOMIC GEOGRAPHY CURRICULUM IN OMAN
}

\author{
Ahmed AL-RABAANI *, Sultan Qaboos University - Sultanate of Oman \\ Fathiya AL-WAHAIBI, Ministry of Education - Sultanate of Oman \\ rabaani@ hotmail.com, arabaani@squ.edu.om
}

Received: 22. 11. 2018 / Accepted: 16. 2. 2019

Typ článku: Teoretická studie

DOI: $10.5507 /$ jtie.2019.003

Abstract: This study investigates the effectiveness of using Edmodo to teach the economic geography curriculum in Oman to improve eleventh-grade female students' learning outcomes, using an experimental pre-posttest design, with experimental and control groups of 24 and 28 female students (respectively). An achievement test of economic geography was used to collect data. The results showed that using Edmodo significantly increased female students' achievement.

Key words: Edmodo, female education, economic geography, achievement, students, Oman.

\section{ÚSPĚŠNOST VYUŽÍVÁNÍ SOCIÁLNÍ SÍTĚ EDMODO VE VÝUCE EKONOMICKÉ GEOGRAFIE U STUDENTEK STŘEDNÍ ŠKOLY V OMÁNU}

Abstrakt: Studie zkoumá efektivitu využiváni sociální sítě Edmodo při výuce ekonomické geografie v Ománu, pro zlepšeni studijnich výsledkü u studentek střední školy. Studie využivá experiment pre-posttest designu s experimentální a kontrolní skupinou, které čitaly 24 a 28 studentek. K ziskáni dat byl využit didaktický test z ekonomické geografie. Výsledky studie ukázaly, že využivání Edmodo významně zlepšilo studijní výsledky studentek.

Klíčová slova: Edmodo, vzdělávání žen, ekonomická geografie, úspěšnost, studenti, Omán.

*Autor pro korespondenci: rabaani@hotmail.com 


\section{Introduction}

The current era, since the early 2000 s, can be described as the age of the social network revolution, which has changed concepts of communication between people worldwide. Regardless of their age, gender, socio-economic status and ethnicity, billions of people spend hours and hours connected with others through such networks every day. Such features drive governments, business, national and international organizations and individuals to use social networks to achieve their own diverse goals. Its intrinsic features make it widely used in political, economic and social movements and trends to spread awareness, directing attention to critical or topical issues consumed by social media users.

The Edmodo platform is a revolutionary social network application developed to serve academic purposes by Nicolas Borg and Jeff O'Hara in 2008 and in 2010. It launched features such as subject and publisher communities that enable communication between teachers, parents and students (Chee, 2014). This platform has several advantages that enable teachers to tackle many problems facing them in their classes. According to the official Edmodo (2017) website, it fosters collaboration in a secure and closed environment, whereby teachers monitor all processes, posting assignments and assessments that are automatically graded, creating professional groups, storing and sharing documents and files, and connecting parents. It also provides uploading, sharing links to websites, sharing knowledge and getting feedback, and group formation (CurranSejkora, 2013).

As a social network, Edmodo differs from mainstream platforms such as Facebook etc. as it is dedicated to serving academic purposes (Holland \& Muilenburg, 2011); consequently, its associated features make it very secure for learning environments, with minimal distractions, and it allows bi-directional teacher-learner and learner-learner interaction (Kongcham, 2012). It also helps transfer the teaching process from teachercentered to student-centered teaching (Schiller, 2011), encouraging students to use their initiative and develop their learning autonomy through posting notes, uploading their own materials, writing comments, and exploring multimedia resources (Mokhtar \& Dzakiria, 2015).

Due to its innovative features and manifest scope for practical application, Edmodo has attracted instructors globally who see potential in its offering of an improved teaching and learning experience, fascinating a more dynamic and engaging classroom environment than traditional methods (Greenhow \& Robelia, 2009). It also improves the quality of the learning environment, which is positively reflected in enhanced student participation in the learning environment and externally (Pisey et al., 2012; Balasubramanian \& Fuckey, 2014; Bicen, 2015).

The use of Edmodo contributes to addressing some problems related to enhancing teacher-teacher, student-student and teacher-student collaboration. Kirschner and Karpinski (2010) indicated that the use of Edmodo helped teachers organize collaborative teams for planning and assessment strategies, and this enabled them to work together to address different matters they face in their classes (Conole, 2010). It also promotes teacherstudent and student-student collaboration, increasing communication, enhancing the quality of students work and sharing knowledge (Dowling, 2011; Al-Okaily, 2013; Enriquez 2014; Al-Kathri, 2015), and accelerates the learning process by enabling students to handle different tasks online (Business Wire, 2014), as well as alleviating the limited classroom time available (Mokhtar \& Dzakiria, 2015). 
These features are essential to student achievement. Edmodo has positive effects on students' achievement, which is very critical for any teacher, particularly with those who have difficulty in improving their students' achievement. The results of several studies show that using Edmodo positively affects students' achievement (Aypay, 2010; Nee, 2014; Hankins, 2015; Gay \& Sofyan, 2017; Imam et al., 2017). According to Buescher (2010), Edmodo allows teachers to use different types of assessment tools, such as creating polls, multiple choice quizzes, questions, fill-in-blanks and matching activities. Such tools allow students to receive direct feedback and often generate more enthusiasm than more orthodox learning activities (Chandler \& Redman, 2013).

Due to its intrinsic advantages (i.e. consumer satisfaction), Edmodo was had accrued a total of 75 million net users by 2018 (Edmodo, 2018). According to Majd (2011), around $66 \%$ of students believe that it is useful, $79 \%$ think that it helps them in their study, and $78 \%$ feel happy with using them in their lesson. Using Edmodo clearly effects differences in the classroom environment for both students and teachers. Its purported and demonstrable advantages have brought Edmodo wide research attention, particularly investigations of its effectiveness in different learning environments and cultures, but most literature has pertained to teaching and learning English (particularly English as a Foreign Language), with very little dedicated consideration of its use in teaching social studies.

To address this research gap, the current study investigates the effectiveness of Edmodo in teaching the economic geography textbook in the social studies for grade 11 in the Sultanate of Oman. In addition to investigating Edmodo, this is particularly important for social studies pedagogical research as previous studies demonstrated that Omani students have negative attitudes towards social studies curriculum (Al-Karosi, 2014) and issues of low achievement in this subject (Al-Shauli \& Al-Rabaani, 2011; Al-Yahyeei, 2012; Al-Wahaibi, 2018). It is also generally useful to explore the effectiveness of Edmodo in different school curriculum areas rather than focusing on core subjects like English and science.

\section{Research}

\subsection{Research Question}

1. How effective is Edmodo in developing the achievement of eleventh-grade female economic geography students in Oman?

\subsection{Aims}

The current study aims to achieve the following:

1. Measuring the efficiency of using the Edmodo in developing achievement of eleventh-grade female students in economic geography in Oman.

\subsection{Limitations}

- Gender: Female students.

- Grade level: Grade eleven female students registered in the school year (2016/2017).

- Place: A sample of the schools of Muscat Governorate, Oman. 


\subsection{Methodology}

\subsubsection{Research Design}

This study adopts a quasi-experimental methodology to evaluate the efficiency of Edmodo in developing eleventh-grade female students' achievement, based on an experimental study of a control group receiving traditional teaching methods (use dialog, discussion, pictures, hardcopy materials, and face-to-face commination) for social studies and the experimental group receiving Edmodo in teaching, as shown in Table 1. The main outcome measure was an achievement test of curriculum content learned by students, applied before and after the experimental and control teaching interventions. In addition, the researcher observed the application of each method in the studied classrooms and made observational field notes to record key points evident in the pedagogical experience in the classroom.

\begin{tabular}{llll}
\hline $\begin{array}{l}\text { Pre-test } \\
\text { application }\end{array}$ & Study group & $\begin{array}{l}\text { Processing type } \\
(1 / 3-29 / 3 / 2017)\end{array}$ & Post-test application \\
\hline $\begin{array}{l}\text { Achievement } \\
\text { test }\end{array}$ & Experimental & $\begin{array}{l}\text { Teaching the } \\
\text { 'International transport } \\
\text { communication and } \\
\text { trade' unit using } \\
\text { Edmodo }\end{array}$ & $\begin{array}{l}\text { Achievement test on } \\
\text { 'International transport } \\
\text { communication and trade' }\end{array}$ \\
\cline { 2 - 4 } & Control & $\begin{array}{l}\text { Teaching the } \\
\text { 'International transport } \\
\text { communication and } \\
\text { trade' unit using } \\
\text { traditional teaching } \\
\text { methods }\end{array}$ & $\begin{array}{l}\text { Achievement test on } \\
\text { 'International transport } \\
\text { communication and trade' }\end{array}$ \\
& & & \\
& & &
\end{tabular}

\subsubsection{Sample}

Table no. 1: Study quasi-experimental design

The study sample consisted of 52 eleventh-grade students selected from Al-Amerat Post Basic School (for children aged 16-18). All participants were female due to expediency (boys and girls in Oman receive separate education from the third grade onwards) and to explore the particular experience of girls, as explained previously. It is an intentional sample, as the school is near the researchers' place of residence, and due to the availability of all means of application, administrative and technical facilities required. The study sample was divided into experimental and control groups. Table 2 shows the distribution of sample members in both groups.

\begin{tabular}{ccccc}
\hline \multicolumn{2}{c}{ Control group } & \multicolumn{2}{c}{ Experimental group } & Total \\
\hline Class & Number & Class & Number & \\
\cline { 1 - 3 } $10 / 11$ & 28 & $11 / 11$ & 24 & 52 \\
\hline
\end{tabular}

Table no. 2: Group distribution 


\subsubsection{Equivalence of Both Groups}

Pre-test application was used to ensure the equivalence of the groups, so that subsequent comparison was meaningful. The results indicated that there was no statistically significant difference, as indicated in Table 3.

\begin{tabular}{ccccccc}
\hline Group & Number & Mean & SD & df & $\begin{array}{c}(\mathrm{T}) \\
\text { Value }\end{array}$ & Sig \\
\hline Experimental & 24 & 5.37 & 2.56 & & .554 & \multirow{2}{*}{50} \\
\hline Control & 28 & 5.75 & 2.31 & & & $.264^{*}$ \\
\hline
\end{tabular}

$*$ There are no statistically significant differences at $(\alpha=0.05)$ level, Test Total Degree $=20$

Table no. 3: Pre-test percentage of averages, measurement deviations, and (C) Value

\subsubsection{Achievement Test}

An achievement test was developed that consisted of 20 questions developed based on the objectives of the economic geography textbook.

\subsubsection{Validity and Reliability}

The validity of the achievement test was evaluated by a panel of judges by applying them in the pre-test. The reliability of the achievement test was (.748).

\subsection{Results}

The results showed that there were significant differences in achievement between the control and experimental groups in favor of the latter. This was clearly obvious in the experimental group's achievement in the pre-test of 5.37 (of a total of 20), rising to 16.8 in the post-test; in contrast, the control group achieved 5.75 and 12.25 pre- and post-test (respectively). These results indicate the effectiveness of Edmodo in developing students' achievement in economic geography.

\begin{tabular}{|c|c|c|c|c|c|c|}
\hline Test & Groups & Mean & SD & $\mathrm{df}$ & $\mathrm{t}$ & sig \\
\hline \multirow{2}{*}{$\begin{array}{c}\text { Pre- } \\
\text { application }\end{array}$} & Experimental & 5.37 & 2.56 & \multicolumn{3}{|c|}{.554} \\
\hline & Control & 5.75 & 2.31 & 50 & & .264 \\
\hline \multirow{2}{*}{$\begin{array}{c}\text { Post- } \\
\text { application }\end{array}$} & Experimental & 16.8 & 3.90 & \multirow[t]{2}{*}{50} & \multirow[t]{2}{*}{4.821} & \multirow[t]{2}{*}{$0.000 *$} \\
\hline & Control & 12.25 & 2.44 & & & \\
\hline
\end{tabular}

$*$ There are statistically significant differences at $(\alpha=0.05)$ level

Table no. 4: Pre-and post-test percentage of averages, measurement deviations, and $(C)$ Value

\subsection{Discussion}

Based on the findings, it can be stated that using Edmodo in teaching economic geography significantly improves students' achievement compared to using traditional methods. This result could be attributed to the great improvement in the classroom environment made by Edmodo, whereby it becomes very positive and attractive for students. The effect of Edmodo was clearly observed through students' engagement and excitement during the lesson. The students did not feel bored and they felt that the length 
of the lesson was very short, because they enjoyed learning through Edmodo. Such results support the results of previous studies in affirming that using Edmodo in teaching improved the quality of the classroom environment (Balasubramanian \& Fuckey, 2014; Pisey et al., 2012; Bicen, 2015; Greenhow \& Robelia, 2009; Majd, 2011).

The improvement of students' achievement could be attributed to other factors such as teachers' ability to present the materials in different and attractive ways, such as pdf, PowerPoint, multimedia, photos, graphs, maps, and online encyclopedias. In addition, Edmodo itself encourages students to actively participate in the development of subject material through uploading their own files in the Edmodo library. The students feel more excited and enthusiastic when they upload their files and documents to the library. These results agree with other studies, which showed that Edmodo enables teachers to present their materials in different ways and allows students to contribute to building up an online database (Schiller, 2011; Kongcham, 2012; Mokhtar \& Dzakiria, 2015).

Female students' engagement and achievement in social studies was effectively enhanced by using Edomodo, particularly in terms of increasing interactions with each other, during the lesson and at home, in order to complete their activities, and to share knowledge or materials they gathered from different sources. Edmodo also stimulated female students who used to be less active in the class to participate through group work or individual activities. The results support previous studies which indicated that Edmodo enhances students' interaction (Pisey et al., 2012; Balasubramanian \& Fuckey, 2014; BusinessWire, 2014; Bicen, 2015; Mokhtar \& Dzakiria, 2015). Edmodo provides students with space for face-to-face discussion during the lesson and in collaboration to complete activities, helping each other and working collaboratively to support each other, including with technical application (e.g. if users have difficulty in dealing with icon in the suite). Such results support what has been found from previous studies, in that Edmodo improves students' involvement in the learning process and sharing knowledge (Dowling, 2011; AlOkaily, 2013; Enriquez 2014; Al-Kathri, 2015).

Students' achievement is also influenced by direct feedback in Edmodo, which allows students to evaluate their achievement level, weakness and motivate them to develop their knowledge and skills. Also, Edmodo provides fairness, whereby no students are excluded from answering any questions, because all students should answer questions in the site, not as in the case of traditional method where teachers ask verbal questions and only one or two students answer them.

In addition, student achievement is effected positively by Edmodo helping both teachers and students override the time limitations of the traditional lesson format. This feature enables students to read more and do more practice individually, individually with others' support, or within groups, in appropriate times for them. Thus, it was noticed that the experimental group did not have any problems in completing tasks compared to the control group, which used traditional methods.

A notable change was evident in the teachers' role in the class, with the experimental group moving away from teacher-centered toward student-centered learning, which has advantages in freeing up teacher time to targeted intervention to support individual learning needs, supervising students' progress and helping students who have some difficulties. This also allows teachers more time to enrich the subject and diversify the and update the learning material, as well as enhancing the teacher-student relationship, which was positively reflected in students' perceptions about the subject. 


\section{Conclusion}

The results showed that using Edmodo has a positive effect on female students' achievement in the economic geography subject of the social studies curriculum in Oman, due to its features which improve the quality of learning environment for both teachers and students. It also allows the display of economic geography material in more attractive and engaging way compared to the traditional method, and it enhances students' involvements in all steps of the learning process, during classroom time and at home, through communicating with their peers and teachers.

\section{Acknowledgement}

We would like to acknowledge all those who have contributed in conducting this study, including students in the experimental and control groups, cooperative teachers and school leaders.

\section{Bibliography}

Al-Karosi, S. (2014). Omani governmental and private school students' attitudes towards the social studies curriculum. MA thesis, Sultan Qaboos University.

Al-Kathiri, F. (2015). Beyond the classroom walls: Edmodo in Saudi secondary school EFL instruction: attitudes and challenges. English Language Teaching, 8(1), 189-203.

Al-Okaily, R. (2013). Mobile learning and BYOD: Implementations in an Intensive English Program. Learning and Teaching in Higher Education: Gulf Perspectives, 10(2), 1-7.

Al-Shuaili, A. \& Al-Rabaani, A. (2010). The climate changes awareness among science and social sciences student teachers at Sultan Qaboos. Journal of Educational Science, 6(4), 269-284.

Al-Wahaibi. F. (2018). Economic literacy of Omani 11 grade post basic education students. MA thesis, Sultan Qaboos University.

Al-Yahyeei, R. (2012). Water awareness among post basic education students in the Sultanate of Oman. MA thesis, Sultan Qaboos University.

Aypay, A. (2010). Information and communication technology (ICT) usage and achievement of Turkish students in PISA 2006. Turkish Online Journal of Educational Technology, 9(2), 116-124.

Balasubramaniana, K. \& Fukey, L. (2014). A study on 'Student preference towards the use of Edmodo as a learning platform to create responsible learning environment'. Procedia Social and Behavioral Sciences, 144, $416-422$.

Bicen, H. (2015). The role of social learning networks in mobile assisted language learning: Edmodo as a case study. Journal of Universal Computer Science, 21(10), 12971306.

Buescher, E. (2010). Edmodo: A white paper. Retrieved June 13, 2018 from http://coe.winthrop.edu/jonesmg/LTI/2010Fwhitepapers/Eileen_Buescher.pdf

Business Wire (2014). Edmodo releases App for Windows 8.1 at ISTE 2014. Retrieved June 13, $2018 \quad$ from https://www.businesswire.com/news/home/20140628005006/en/Edmodo-Releases-AppWindows-8.1-ISTE-2014

Chandler, P. D. and Redman, C. (2013). Teaching teachers for the future: Modelling and exploring immersive personal learning networks. Australian Educational Computing, 27(3), 54-62. 
Conole, G. (2010). Facilitating new forms of discourse for learning and teaching: Harnessing the power of Web 2.0 practices. Open Learning, 25(2), 141-151. https://doi.org/10.1080/02680511003787438

Curran-Sejkora, E. (2013). Student interactions in Edmodo versus Facebook. Phd dissertation, Arizona State University. Retrieved June 13, 2018 from https://repository.asu.edu/attachments/125827/content/CurranSejkora_asu_0010E_13432 .pdf

Dowling, S. (2011). Web-based learning-Moving from learning islands to learning environments. TESLEJ, 15(2), 1-27.

Edmodo (2017). The Edmodo quick start guide. Retrieved June 13, 2018 from https://www.dallasisd.org/cms/lib/TX01001475/Centricity/Domain/111/edmodoquickstar tguide.pdf

Edmodo (2018). 75 million user celebration. Retrieved June 13, 2018 from https://www.edmodo.com/topics/7062/75-Million-Users-Celebration.

Enriquez, M. A. S. (2014). Students' perceptions on the effectiveness of the use of Edmodo as a supplementary tool for learning. DLSU Research Congress 2014 De La Salle University, Manila, Philippines, March 6-8. Retrieved June 13, 2018 from www.dlsu.edu.ph/conferences/dlsu_research_congress/2014/_pdf/proceedings/LLI-II010-FT.pdf

Gay, E. \& Sofyan, N. (2017). The effectiveness of using Edmodo in in enhancing students' ouctomes in advance writing course of the fifth semester at FIp-UMMU. Journal of English Education, 2(1)1-11.

Greenhow, C. \& Robelia, B. (2009). Old communication, new literacies: Social network sites as social learning resources. Journal of Computer-Mediated Communication, 14(4), 1130-1161. http://dx.doi.org/10.1111/j.1083-6101.2009.01484.x

Hankins, S. (2015). The effect of Edmodo on students achievement in middle school. Phd dissertation, St Thomas University, Florida. Retrieved June 13, 2018 from http://www.academia.edu/14559020/Effects_of_Edmodo_on_Student_Achievement

Holland, C. \& Muilenburg, L. (2011). Supporting student collaboration: Edmodo in the classroom. In M. Koehler \& P. Mishra (Eds.), Proceedings of SITE 2011: Society for Information Technology \& Teacher Education International Conference (pp. 3232-3236). Nashville, TN: Association for the Advancement of Computing in Education (AACE). Retrieved June 13, 2018 from https://www.learntechlib.org/primary/p/36816/

Imam, S., Rini, K. \& Sri, S. (2017). The effectiveness of learning materials with Edmodo to enhance the level of students' probablilistic thinking. AIP Conference Proceedings, 1848(1), 040005 (2017). https://doi.org/10.1063/1.4983943

Kirschner, A. \& Karpinski, C. (2010). Facebook and academic performance. Computers in Human Behavior, 26(6), 1237-1245. http://dx.doi.org/10.1016/j.chb.2010.03.024

Kongchan, C. (2012). How a non-digital-native teacher makes use of Edmodo. Proceedings of the 5th Edition of the Pixel International Conference 'ICT for Language Learning', Florence, Italy, November 11-12. Retrieved June 13, 2018 from https://conference.pixel-

online.net/conferences/ICT4LL2012/common/download/Paper_pdf/90-IBT18-FP-

Kongchan-ICT2012.pdf

Majid, N. (2011). The use of information technology in teaching English: An attempt to develop student-centered learning at Telkom Polytechnic. Prosidingkonferensi Nasional 
ICT-M Politeknit Telkom (KNIP). Retrieved June 13, 2018 from http://openjurnal.politekniktelkom.ac.id/

Mokhtar, F. \& Dzakiria, H. (2015). Illuminating the potential of Edmodo as an interactive virtual learning platform for English language learning and teaching. Malaysian Journal of Distance Education, 17(1), 83-98.

Nee, C. (2014). The effect of educational networking on students' performance in biology, International Journal on Integrating Technology in Education, 3(1) 21-41.

Pisey, S., Ramteke, P. L. \& Burghate, B. R. (2012). Mobile learning exploring the challenges and opportunities of distance education. Proceedings of National Conference on Emerging Trends in Computer Technology (NCETCT-2012), R. C. Patel Institute of Technology, Shirpur, Maharashtra, India, 2012, 2(3):19-23.

Schiller, K. (2011). High-tech classrooms. Information Today, 28(8), 34-36. Retrieved June 13, 2018 from http://www.infotoday.com/it/sep11/index.shtml 